\title{
Macro-anatomical variation of the olfactory apparatus in some Indian teleosts with special reference to their ecological habitat
}

\author{
S.K. Sarkar, A. Acharya, S. Jana, S.K. De \\ Ultrastructure and Fish Biology Research Unit, Department of Zoology, Vidyasagar University, Midnapore (West) - 721102, \\ West Bengal, India
}

[Received 3 September 2013; Accepted 3 October 2013]

The anatomy of the peripheral olfactory apparatus (i.e. olfactory lamellae, olfactory chambers, accessory nasal sacs, olfactory nerve tracts, olfactory bulbs and brain) of some teleosts, viz. Pseudapocryptes lanceolatus (Bloch and Schneider, 1801) - an air breathing mudskipper, Lepidocephalichthys guntea (Hamilton, 1822) - a freshwater scavenger fish and Mastacembelus armatus (Lacepède, 1800) - a freshwater potamodromous fish, has been studied in relation to their specific ecological habitat. Live, adult, sex-independent fish species were collected from the local markets of West Bengal, India, and acclimatised with the laboratory conditions (for $72 \mathrm{~h}$ at $32^{\circ} \mathrm{C}$ ). The specimens were anaesthetised by MS-222 (dose: 100-200 mg/L). Olfactory apparatuses were dissected out and fixed in aqueous Bouin's solution. The macro- and microstructures (using haematoxylin and eosin) of the olfactory apparatuses were examined under binocular light microscope (LM) and trinocular LM (Primo Star; Carl Zeiss Microscpy, GmbH, Germany) respectively. P. lanceolatus possesses unilamellar olfactory apparatus at the rounded snout, whereas L. guntea shows small rosette with 18 to 24 lamellae on either side of the elliptical snout. Elongated olfactory rosette (number of lamellae ranges from 60 to 76) is present at the pointed snout of M. armatus. Morpho-anatomical variation in snout structure of the respective species is an indicative of divergence in ecological habitat, but variation in olfactory apparatus is significant for species-specific differentiation. Pseudostratified olfactory neuroepithelial components (i.e. sensory receptor cell, supporting cell and basal cell) show striking similarities amongst these species. Therefore comparative anatomical changes of the snout and olfactory apparatus are not only representing ecological habitat based on interspecific variation, but may also indicate the phylogenetic relation amongst said species. (Folia Morphol 2014; 73, 2: 122-128)

Key words: Pseudapocryptes lanceolatus, Lepidocephalichthys guntea, Mastacembelus armatus, olfactory, pseudostratified, neuroepithelium

Address for correspondence: Prof. S.K. De, Ultrastructure and Fish Biology Research Unit, Department of Zoology, Vidyasagar University, Midnapore (West) - 721102, West Bengal, India, fax: (+91) 03222-275329, e-mail: skdvu@yahoo.co.in 


\section{INTRODUCTION}

Teleosts are the most diverse taxon of all the vertebrates [11]. This group shows enormous diversity in their ecological habitat, ranging from tropical reefs to abyssal depths of the aquatic environment [2]. Morphological pattern of the body structure of teleost may depend on the specific ecological habitat of the species $[23,24]$. Chemical senses (i.e. olfaction, gustation, etc.) of teleost play a vital role in searching the food as well as habitat selection of the species $[8,9,16]$. This sense is involved in the detection and discrimination of different chemical cues from the external environment [22]. The olfaction in teleosts is mediated through the specific anatomical organ, viz. olfactory apparatus, which is comprised of olfactory lamellae, olfactory chambers, accessory nasal sacs, olfactory nerve tracts and brain $[1,7]$. Anatomical diversity of this neurosensory structure $[3,15]$ is of great significance in fish taxonomy and phylogeny $[19,20]$, but the habitat based on ecomorphological variation of the peripheral olfactory apparatus in teleosts is still an obscure part in fish biology. Pseudapocryptes lanceolatus (Bloch and Schneider, 1801), Lepidocephalichthys guntea (Hamilton, 1822) and Mastacembelus armatus (Lacepède, 1800) of different teleostean taxa and ecological habitat are considered to understand the ecomorphological variation of the olfactory apparatus. These species are commonly bottom-dwelling, but are found in different environmental conditions. Pseudapocryptes lanceolatus is an air-breathing mudskipper and generally can be found on the coastal mudflats, intertidal zone of South Bengal. Lepidocephalichthys guntea is a common freshwater scavenger fish of river Ganga and generally can be found in shallow, slow-moving sections of streams. Mastacembelus armatus is a freshwater species and potamodromous in nature. This exercise highlights the detail morphological diversity of the snout and peripheral olfactory system in $P$. lanceolatus, L. guntea and $M$. armatus respectively in relation to their specific ecological habitat.

\section{MATERIALS AND METHODS}

Live, adult, disease-free and sex-independent $P$. lanceolatus, L. guntea and $M$. armatus were collected from the different local markets of West Bengal and brought to the laboratory. The fishes were acclimatised in the laboratory conditions for $72 \mathrm{~h}$ at room temperature $\left(32^{\circ} \mathrm{C}\right)$ and anaesthetised by MS-222 (dose: 100-200 mg/L). The experimental specimens were then fixed in aqueous Bouin's solution for $12 \mathrm{~h}$. Olfactory apparatus was dissected out from the antero-dorsal part of the head and examined under binocular light microscope. For the histological study, the dissected olfactory apparatuses of $P$. lanceolatus, L. guntea and $M$. armatus were separately fixed in aqueous Bouin's solution for $1 \mathrm{~h}$. After fixation, olfactory apparatuses were washed in $70 \%$ ethanol and then dehydrated in graded ethanol followed by clearing in xylene. The tissues were then embedded in paraffin wax of $56-58^{\circ} \mathrm{C}$ under a thermostat vacuum paraffin-embedding bath for a period of $1 \mathrm{~h}$. The serial thin sections (about $4 \mu \mathrm{m}$ ) of the olfactory lamellae were cut by rotary microtome. The tissues were stretched on Mayer's albuminised glass slide and then stained with haematoxylin-eosin stain. Stained sections were examined under trinocular microscope (Primo Star; Carl Zeiss Microscpy, GmbH, Germany) and image-analysed by Axio Vision LE (version 4.3.0.101) (Carl Zeiss Vision, GmbH, Germany).

\section{RESULTS}

The olfactory apparatus of Pseudapocryptes lanceolatus (Fig. 1A) is present at the frontal part of the rounded snout in-between the nostrils (Fig. 1B). It comprises of single olfactory lamella along with ethmoidal sac and lacrimal sac, olfactory chambers, olfactory nerves and brain (Fig. 2A, B). The nostrils, i.e. anterior nostril and posterior nostril, are located at a distance of about $6 \mathrm{~mm}$ from each other. The anterior nostril is a tube-like structure, present at the apical tip of the snout and projected antero-downwardly. The posterior nostril is an oval-shaped aperture located just anterior to the eye (Fig. 1B). These nostrils are well associated with olfactory lamella, which is an elongated tube-like structure (Fig. $2 \mathrm{~A}, \mathrm{~B})$. This structure is partly guarded by bony olfactory chambers (Fig. 2B). The nasal cavity has an open communication with the nostrils and present within the olfactory lamella. Diameter of nasal cavity is gradually increased towards the posterior part of the olfactory lamella. The accessory nasal sacs, viz. ethmoidal sac and lacrimal sac, are morphologically different and are present at the posterior part (i.e. dorsocaudal and ventrocaudal region) of the olfactory lamella (Fig. 2B). Paired olfactory nerves are originated from the distal part of the olfactory lamella and travel together relatively long distance (about $10 \mathrm{~mm}$ ) to connect with the olfactory bulb of the brain (Fig. 2A, B). The subdivision of the brain in 


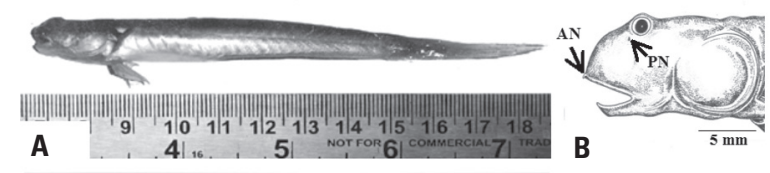

Figure 1. A. The photograph shows external morphology of the air-breathing coastal mudskipper, viz. Pseudapocryptes lanceolatus (Bloch and Schneider, 1801) (order: Perciformes; family: Gobiidae); B. Diagrammatic representation of rounded snout region of $P$. lanceolatus that possesses distinct anterior nostril (AN) and posterior nostril (PN). The nostrils are lying at a distance from each other.

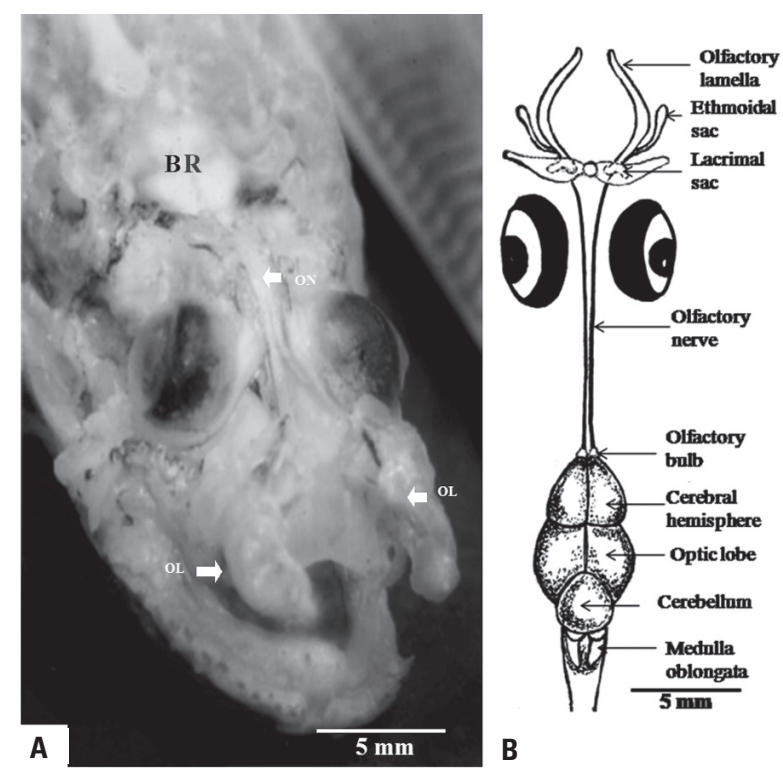

Figure 2. A, B. The photograph and diagram show the olfactory apparatus of $P$. lanceolatus, which comprises of single olfactory lamella (OL), ethmoidal sac, lacrimal sac, olfactory chamber, olfactory nerve (ON) and brain (BR) (olfactory bulb, cerebral hemisphere, optic lobe, cerebellum, medulla oblongata, etc.).
$P$. lanceolatus is noted from the dorsal view as olfactory bulb, cerebral hemisphere, optic lobe, cerebellum, medulla oblongata, etc. (Fig. 2B). The olfactory bulb of the $P$. lanceolatus is anatomically attached to the frontal part of the brain. Histologically, olfactory lamella is externally lined by pseudostratified olfactory neuroepithelium, which encloses the nasal cavity (Fig. 3A, B). Olfactory neuroepithelium comprises of sensory receptor cell, supporting cell and basal cell. Sensory receptor cells are bipolar neuron in nature and possess dendron, perikaryon and axon (Fig. 3B). Perikaryons are generally marked at the different depth of the olfactory neuroepithelium. Supporting cells are columnar in nature and extend from the apical part to the basal lamina. Several axonal bundles are present just beneath the basal lamina, i.e. fila olfactoria region (Fig. 3A, B).

Lepidocephalichthys guntea (Fig. 4A) also possesses 2 pairs of nostrils, viz. anterior nostril and posterior nostril. These are located on short elliptical snout of $L$. guntea at a distance measuring about $1 \mathrm{~mm}$ (approx.) (Fig. 4B). The anterior nostril is a short, tube-like structure and is projected outwardly. The posterior nostril is a slightly transverse, slit-like aperture and is located at the anterior edge of the eye (Fig. 4B). The bony olfactory chamber is located in-between 2 nostrils. The olfactory apparatus of $L$. guntea comprises of olfactory chambers, olfactory rosette, accessory nasal sacs, olfactory bulbs, olfactory nerve tracts and olfactory lobes of the brain (Fig. 5A, B). Paired olfactory rosette is located within the olfactory chamber at the dorso-lateral region of the head. This rosette is roughly elliptical in shape and multilamellar in
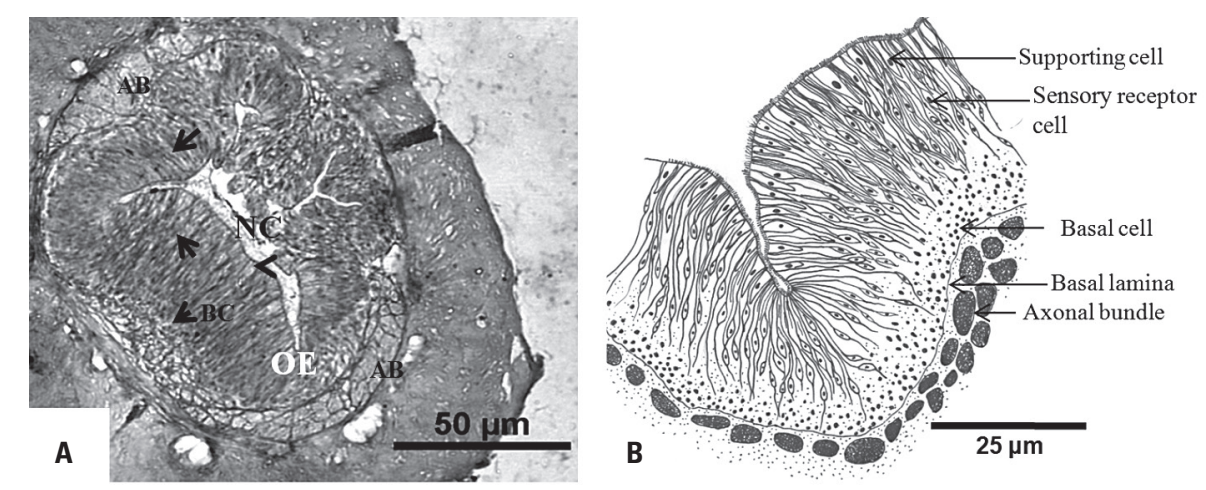

Figure 3. A, B. The transverse section of the single olfactory lamella in $P$. lanceolatus shows pseudostratified olfactory neuroepithelium (OE), which encloses the nasal cavity (NC). The olfactory neuroepithelium possesses sensory receptor cells (arrows), supporting cell (arrow head), basal cell (BC), etc. Several axonal bundles (AB) are also marked just beneath the basal lamina. 

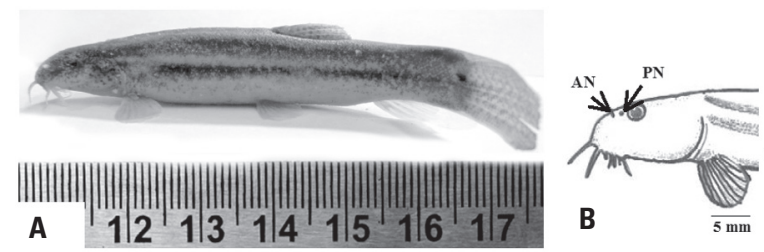

Figure 4. A. The external morphology of Lepidocephalichthys guntea (Hamilton, 1822) (order: Cypriniformes; family: Cobitidae), a common freshwater scavenger fish of the South East Asia; B. The snout of $L$. guntea is elliptical in shape and possesses anterior nostril (AN) and posterior nostril (PN), located in front of the eye. The nostrils are very closely associated with each other.

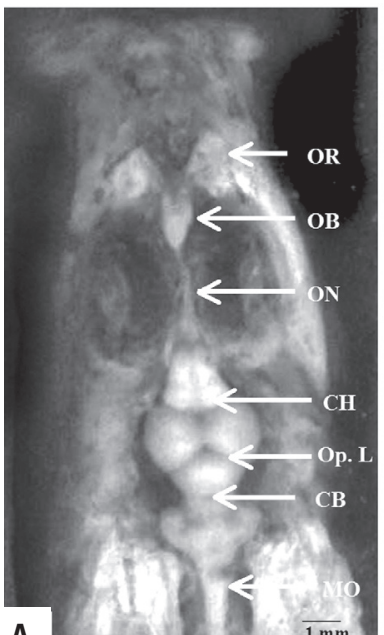

A

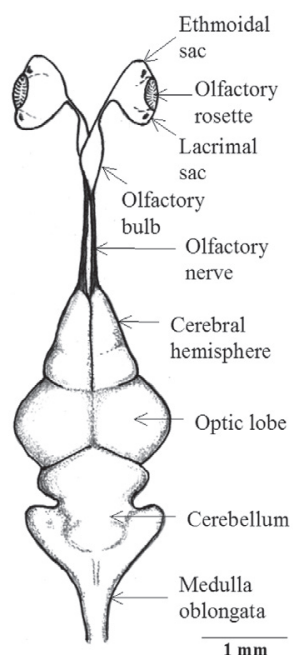

Figure 5. A, B. The anatomical photograph and diagram represent the olfactory apparatus of $L$. guntea. The olfactory apparatus in this species includes small, oval-shaped olfactory rosette (OR), ethmoidal sac, lacrimal sac, olfactory bulbs (OB), olfactory nerve (ON) and brain (cerebral hemisphere [CH], optic lobe [Op.L.], cerebellum [CB], medulla oblongata [MO], etc.). structure (Fig. 5A, B). Total number of the olfactory lamellae in each rosette ranges from 18 to 24 . Each rosette shows 2 rows of olfactory lamellae radiating from the central axis, i.e. olfactory raphae. The accessory nasal sacs, viz. ethmoidal sac and lacrimal sac, are well associated with olfactory rosette at different position (Fig. 5A, B). The ethmoidal sac is located at the antero-dorsal side and the lacrimal sac is located at the postero-ventral side of the olfactory rosette. The olfactory nerve appears from the distal part of the olfactory rosette and immediately projects into the olfactory bulb (Fig. 5A, B). Olfactory bulbs are pear-shaped in structure and are very closely associated to each other. Paired olfactory nerve reappears from the opposite end of the olfactory bulb and travels together $(1.5 \mathrm{~mm}$ approx.) to connect with the olfactory lobe to the brain (Fig. 5A, B). Anatomical subdivision of the brain from the dorsal view is also noted. Microanatomically, the multilamellar olfactory rosette shows externally lining of pseudostratified olfactory neuroepithelium (Fig. 6A, B). This olfactory neuroepithelium also shows common cellular components, like sensory receptor cells, supporting cells and basal cell (Fig. 6A, B). These cells are generally distributed throughout the neuroepithelium of the olfactory rosette. The epithelial folding of the olfactory neuroepithelium in L. guntea is distinct (Fig. 6A, B). The fila olfactoria region is apparently shorter than $P$. lanceolatus and present beneath the basal lamina (Fig. 6A, B). Axonal bundles are not prominent in this fila olfactoria. Glomeruli-like structures are clearly noted within the olfactory bulb of $L$. guntea (Fig. 6C).

In Mastacembelus armatus (Fig. 7A), the anterior and posterior nostrils are lying far apart from each
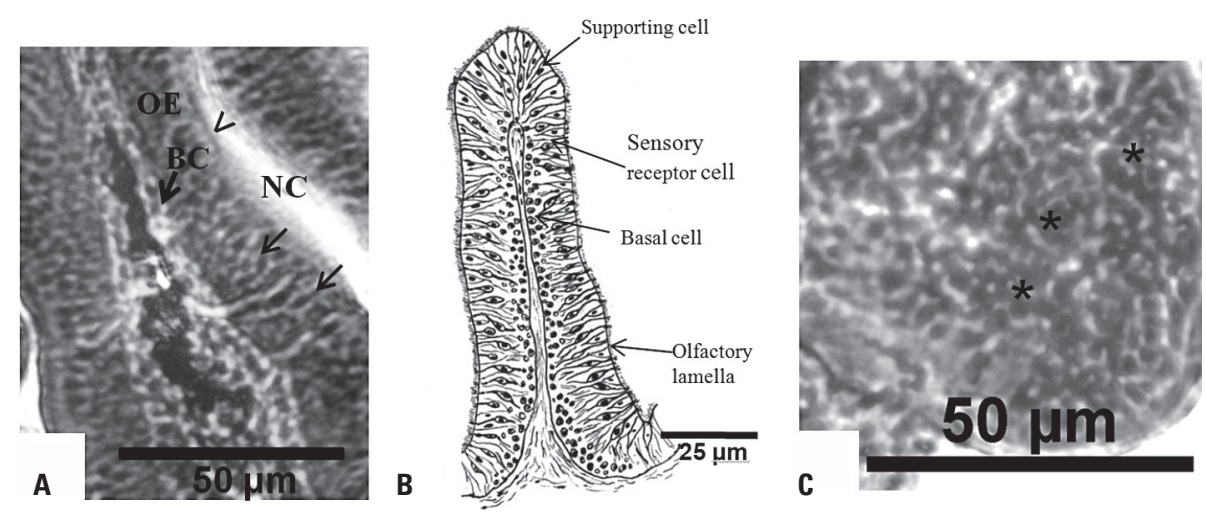

Figure 6. A, B. The transverse section of the olfactory rosette of $L$. guntea multiple neuroepithelial folding around the nasal cavity (NC). The olfactory neuroepithelium $(\mathrm{OE})$ is the pseudostratified structure and comprises of sensory receptor cells (arrows), supporting cell (arrow head), basal cell (BC), etc.; C. The histological section shows large accumulation of glomeruli-like structures (stars) within the olfactory bulb in L. guntea. 


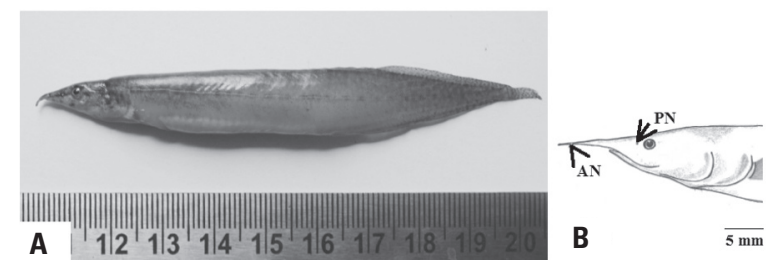

Figure 7. A. The photograph of Mastacembelus armatus (Lacepède, 1800) (order: Synbranchiformes; family: Mastacemlidae), showing distinct external morphology; B. The snout of $M$. armatus is long and pointed, represented in diagram. The distance between the anterior nostril (AN) and posterior nostril (PN) in M. armatus is comparatively greater than in $P$. lanceolatus and $L$. guntea.
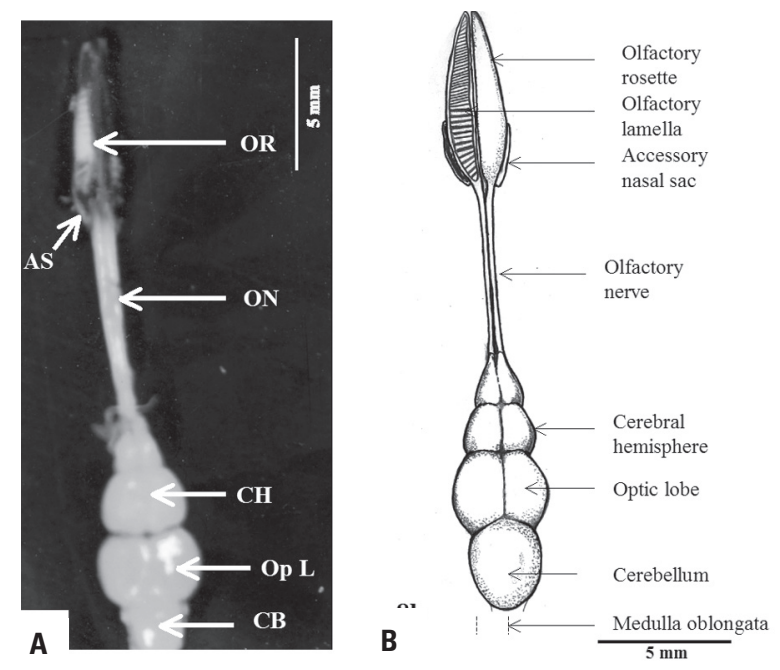

Figure 8. A, B. The olfactory apparatus of $M$. armatus comprises of elongated olfactory rosette (OR), accessory nasal sac (AS), olfactory nerve $(\mathrm{ON})$ and brain (cerebral hemisphere $[\mathrm{CH}]$, optic lobe $[0 p \mathrm{~L})$, cerebellum $[\mathrm{CB}]$, medulla oblongata, etc.). other (Fig. 7B). The anterior nostrils are tube-like in structure and projected obliquely from the apical tip of the elongated snout. The posterior nostrils are small, oval-shaped aperture and are located near the eye. The olfactory apparatus of $M$. armatus comprises of olfactory chambers, olfactory rosette, single accessory nasal sac, olfactory nerve tracts and brain (Fig. 8A, B). The olfactory chamber is membranous in structure and encapsulates the olfactory rosette. The elongated olfactory rosette is paired and multilamellar in nature (Fig. 8A, B). The rosette is present at the apical tip of the snout in-between the nostrils. Each olfactory rosette shows parallel arrangement of the olfactory lamellae, radiating from the central raphae. Number of the olfactory lamellae ranges from 60 to 76 (Fig. 8A, B). A single accessory nasal sac is associated at the caudal region of the olfactory rosette (Fig. 8A, B). The olfactory nerve tracts are paired and originate from the base of the olfactory rosette. These nerve tracts lay very close to each other and are connected with the olfactory bulb, which is located at the ventral part of the telencephalon (Fig. 8A, B). Cerebral hemisphere, optic lobe, cerebellum and medulla oblongata are the prominent subdivision of the brain (from the dorsal view). The histological section of the olfactory rosette shows longitudinal arrangement of lamella with olfactory neuroepithelium (Fig. 9A). Olfactory neuroepithelium is pseudostratified in nature and also comprises of sensory receptor cell, supporting cell and basal cell (Fig. 9B, C). These cells are frequently distributed over the entire neuroepithelium.
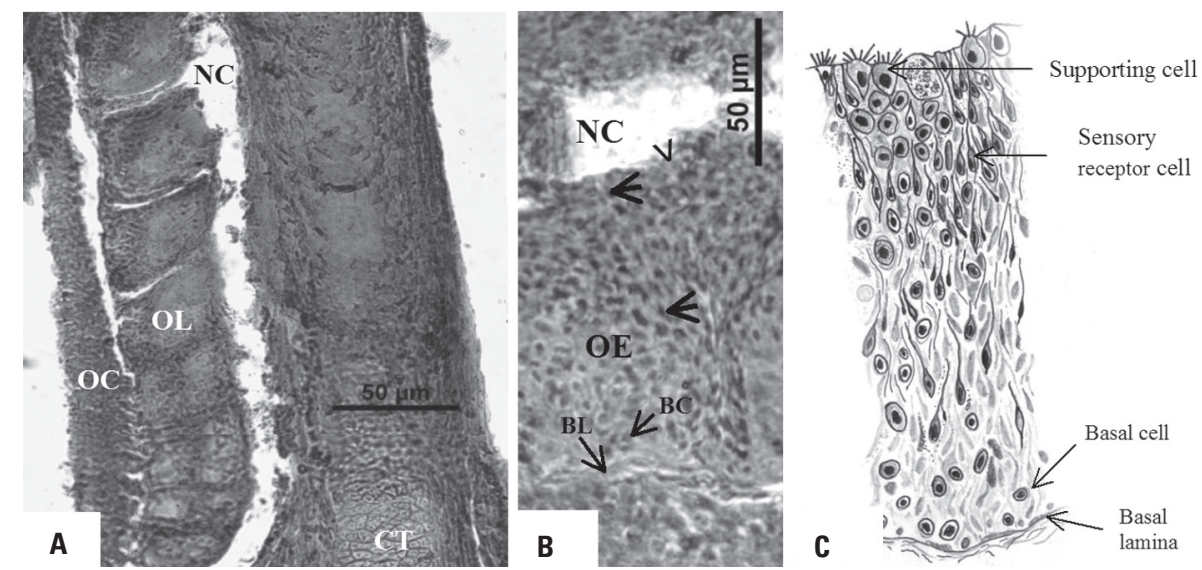

Figure 9. A, B, C. The histological micrographs of the elongated olfactory rosette of $M$. armatus shows arrangement pattern of olfactory lamella (OL) along with the axis, nasal cavity (NC), cornua trabeculae (CT) at the distal part, olfactory chamber (OC), etc. C. The diagrammatic representation of olfactory neuroepithelium (OE) in $M$. armatus possesses sensory receptor cell (arrow head), basal cell (BC), etc., resting on the basal lamina (BL). [Not to Scale.] 
The number of neuroepithelial folding is greater than in L. guntea and results in the large number of olfactory lamellae within the rosette, as noted in the anatomical study. The prominent presence of cornua trabeculae at the both ends of the olfactory rosette is very interesting in $M$. armatus (Fig. 9A).

\section{DISCUSSION}

Chemoreception is an important sensory mechanism in fish, which helps to recognise prey or potential mates and favourable habitat within the aquatic environment [9]. The olfactory apparatus of fish can perceive chemical odorants from the aquatic environment through the nostrils [5]. The external variation of the snout, nostrils and olfactory apparatus in $P$. lanceolatus, $L$. guntea and $M$. armatus are demarcated in different aspects, viz. distance between the nostrils, number of olfactory lamellae, occurrence of accessory nasal sacs, length of the olfactory nerve tracts, neuroepithelial folding, etc. The morphometry of the snout in fish may be related to the ecological niche based on the feeding behaviour of the respective species [25]. Variation in snout morphology may denote the diversity of foraging pattern as well as habitat preference of the species [18]. The external structures of snout in $P$. lanceolatus, L. guntea and $M$. armatus are also variable, what may indicate differences in ecological habitat and feeding habits. The olfactory apparatus of fish is present at the snout region of the head. Anatomical difference in this chemosensory apparatus is not correlated with the variable olfactory sensitivity in the species [26]. This phenomenon may be interpreted as the species-specific variation between the experimental specimens. The olfactory sensitivity is directly related to the physical interaction of the sensory receptor cells and chemical odorants during water ventilation over the olfactory neuroepithelium [4]. The occurrence of the olfactory neuroepithelial cells (viz. sensory receptor cell, supporting cell and basal cell) is very similar amongst the experimental specimens and probably plays a vital role in olfactory sensitivity in fish $[5,8]$. However, the increased lamellar surface of the olfactory neuroepithelium is caused by the frequent neuroepithelial folding to form olfactory rosette [8]. Number of the olfactory lamellae within the olfactory rosette of $L$. guntea and $M$. armatus represents the interspecific variation. Flat olfactory neuroepithelium of $P$. lanceolatus may be noteworthy for benthic habitat, as proposed by
Burne [3]. Additionally, the occurrence of accessory nasal sacs in $P$. lanceolatus, L. guntea and $M$. armatus may be an anatomical evidence of sedentary bottom-dwelling nature $[10,13]$, but the existing variation may be interphyletic. The structural diversity of the snout, nostrils and olfactory apparatus is more prominent, as they are directly exposed to the external aquatic environment. These variations may be noted as adaptive characters for specific habitat of the respective species. The central nervous system (viz. brain) exhibits functional diversity in structure, shape and size amongst various groups of fishes $[6,12]$. The subdivisions of the brain are responsible for different neural functions [14]. Structural divergence in the morphology of brain probably reflects the diversity in ecological habitat and feeding behaviour of the species [21]. Structure of the brain is related to the ecological conditions, but comparative study on the brain morphology in teleosts belonging to the similar ecological habitat also shows diversity. Kortschal et al. [17] reported that both phylogenetic and ecological factors are responsible for interspecific variation of the brain in teleosts. We assume that structural diversity in brain morphology is an indicator of interphyletic distance amongst the species.

\section{CONCLUSIONS}

The comparative anatomical changes of the snout and olfactory apparatus are not only representing ecological habitat based interspecific variation, but may also indicate the phylogenetic relation amongst said species.

\section{ACKNOWLEDGEMENTS}

Prof. Subrata Kumar De (PI) and Swaraj Kumar Sarkar (Research Student) are thankful to University Grants Commission (UGC), New Delhi, India for providing the financial support (Major Research Project: F. No. 41-161/2012 [SR] dated 13.07.2012).

\section{REFERENCES}

1. Biswas S, Datta NC, Sarkar SK, De SK (2013) Anatomical variation in the olfactory apparatus of marine teleosts. J Res Biol, 3: 742-748.

2. Bone Q, Moore RH (2008) Biology of fishes. $3^{\text {rd }}$ Ed. Taylor \& Francis Group, US and UK, pp. 289-345.

3. Burne RH (1909) The anatomy of the olfactory organ of teleostean fishes. Proc Zool Soc London, 2: 610-663.

4. Cox JPL (2008) Hydrodynamic aspects of fish olfaction. J R Soc Interface, 5: 575-593.

5. Døving KB, Dubois-Dauphin M, Holley A, Jourdan F (1977) Functional anatomy of the olfactory organ of fish and 
the ciliary mechanism of water transport. Acta. Zool, 58: 245-255.

6. Evans HM (1937) A comparative study of the brains in pleuronectidae. Proc Roy Soc London, 122B: 308-343.

7. Hamdani EH, Døving KB (2007) The functional organization of the fish olfactory system. Prog Neurobiol, 82: 80-86.

8. Hansen A, Rolen SH, Anderson KT, Morita Y, Caprio J, Finger TE (2003) Correlation between olfactory receptor cell type and function in the channel catfish. J Neurosci, 23: 9328-9339.

9. Hara TJ (1975) Olfaction in fish. Prog Neurobiol, 5: 271-335.

10. Hara TJ, Zeilensky B (2006) Sensory systems neuroscience. In: Fish physiology. Vol. 25. Academic Press, USA and UK, pp. 6-14.

11. Helfman G, Collette BB, Facey DE, Bowen BW (2009) The diversity of fishes: biology, evolution, and ecology. $2^{\text {nd }} \mathrm{Ed}$. John Wiley \& Sons Ltd., Oxford, UK.

12. Huber R, van Staaden M, Kaufman LS, Liem KF (1997) Microhabitat use, trophic patterns and the evolution of brain structure in African cichlids. Brain Behav Evol, 50: 167-182.

13. Kapoor AS, Ojha PP (1972) Functional anatomy of the olfactory organs in the moray Muraena undulata. Jap J Ichthyol, 19: 82-88.

14. Kardong KV (2006) Vertebrates - comparative anatomy, function, evolution. $4^{\text {th }}$ Ed. Tata McGraw Hill Education Pvt. Ltd. New Delhi, pp. 647-655.

15. Kleerekoper H (1969) Olfaction in fishes. Indiana University Press, Bloomington and London.
16. Kotrschal K, Brandstatter R, Gomahr A, Junger H, Palzenberg $M$ (1990) Brain and sensory system in cyprinid fishes. Chapman \& Hall, London, pp. 284-331.

17. Kotrschal K, Van Staaden MJ, Huber R (1998) Fish brains: evolution and environmental relationships. Rev Fish Biol Fisheries, 8: 373-408.

18. Lauder GV (1982) Patterns of evolution in the feeding mechanism of actinopterygian fishes. Amer Zool, 22: 275-285.

19. Nelson JS (1994) Fishes of the world. $3^{\text {rd }}$ Ed. John Wiley and Sons, Inc. New York.

20. Nelson JS (2006) Fishes of the world. $4^{\text {th }}$ Ed. John Wiley and Sons, Inc. New York.

21. Nieuwenhuys $R$ (1982) An overview of the organization of the brain of actinopterygian fishes. Amer Zool, 22: 287-310.

22. Pifferi S, Boccaccio A, Menini A (2006) Cyclic nucleotide-gated ion channels in sensory transduction. FEBS Lett, 580: 2853-2859.

23. Videler JJ, Wardle CS (1991) Fish swimming stride by stride: speed limits and endurance. Rev Fish Biol Fisheries, 1: $23-40$.

24. Videler JJ (1993) Fish swimming. $1^{\text {st }}$ Ed. Chapman and Hall, London and New York.

25. Whiteley AR (2007) Trophic polymorphism in a riverine fish: morphological, dietary and genetic analysis of mountain whitefish. Biol J Lin Soc, 92: 253-267.

26. Yamamoto M (1982) Comparative morphology of the peripheral olfactory organ in teleosts. In: Hara TJ ed. Chemoreception in fishes. Elsevier, New York, pp. 39-59. 